\title{
Article
}

\section{Exploring Sociology of Education in the Promotion of Sustainability Literacy in Higher Education}

\author{
Sandro Serpa ${ }^{1, *}$, Maria José Sá ${ }^{2}$ \\ 1 University of the Azores, Faculty of Social and Human Sciences, Department of Sociology; \\ Interdisciplinary Centre of Social Sciences - CICS.UAc/CICS.NOVA.UAc, and Interdisciplinary Centre for \\ Childhood and Adolescence - NICA - UAc; sandro.nf.serpa@uac.pt \\ 2 Centre for Research in Higher Education Policies; mjsa@cipes.up.pt \\ * Correspondence: sandro.nf.serpa@uac.pt; Tel.: +351 296650000
}

\begin{abstract}
Sustainability, sustainable development and education for sustainable development are increasingly central concepts, both in social practice and in the field of scientific knowledge. Sociology, and in particular Sociology of Education as a specialised Sociology, can provide relevant contributions in its promotion. This article aims to explore the importance of Sociology of Education in promoting sustainability literacy in higher education, using the Sustainable Development Goals and key competencies (United Nations and UNESCO) as the central reference in this field, and intends, thus, to become an added contribution for this discussion. The article seeks to demonstrate that the learning of sustainability literacy would benefit from the use of a sociological stance throughout this whole process that considers dimensions that are often not directly emphasised and articulated between each other, such as: interconnection of scale levels, sociological imagination, multi-paradigmatic nature, heuristic interdisciplinarity, reflexivity and use of Sociology for action.
\end{abstract}

Keywords: sustainability; sustainable development; education for sustainable development; sociology of education; sustainability literacy; higher education; sustainable development goals.

"If you want to go fast, go alone. If
you want to go far, go together"

(African proverb)

\section{Introduction}

Sustainability is an increasingly central concept, both in social practice and in scientific, economic and even political fields [1-16].

Given the centrality of the concept of sustainability, higher education institutions (HEIs) have come to take on sustainability education as an integral part of their agendas [17]. Thus, education for sustainability has been not only integrated into the curricula of the courses but - and more broadly has permeated education, research, the functioning of HEIs and outreach activities [18].

Social sciences, and in particular Sociology, can potentially provide important contributions in the promotion of sustainability $[2,7,8,19,20,21,22,23]$, although very few studies and publications directly relate Sociology of Education with sustainability [7].

Another concept that is closely connected with sustainability is Sustainable Development (SD). The most commonly used definition of this concept is the one provided by the World Commission on Environment and Development (WCED), which advocates that the purpose of SD is to promote the "adjustment of human behavior to address the needs of the present, without compromising the ability of future generations to meet their own needs" [24] (p. 141), cited in [25] (p. 48). This concept was originally used at the first Earth Summit in Stockholm in 1972 [26] and has gradually gained relevance, especially after the Rio de Janeiro Earth Summit in 1992. 
The aforementioned concepts lead to a third one, which is highly relevant in the context analysed in this article: Education for Sustainable Development (ESD). This concept is defined by Yarime et al. [27] (p. 104), as

[...] a dynamic concept utilizing all aspects of public awareness, education, and training to create and enhance an understanding of the linkages among the diverse issues of sustainable development, of which the objective is to develop the knowledge, skills, perspectives, and values that will empower people of all ages to assume responsibility for creating and enjoying a sustainable future.

Indeed, very recently Opoku and Egbu [25] argued about the growing importance of ESD in Education in general. This positioning is in line with one of the goals defined by UNESCO of promoting ESD, which is also reflected in higher education $[13,28]$.

In this ESD process, the promotion of sustainability literacy is central in enabling informed civic participation. This can be attained through the implementation of competencies in this field $[13,14,28,29]$, in a global context where information, in general, seems increasingly easier to access, which does not necessarily translate into greater informed knowledge that justifies decision-making for practice [30].

This article aims to explore the importance of Sociology of Education in the promotion of sustainability literacy in higher education and, consequently, in the promotion of an awareness and practice of sustainability that, in order to succeed, necessarily entails, in addition to a technological dimension, also a social dimension [31].

So as to fulfil this aim of exploring the contribution of Sociology of Education in the promotion of sustainability literacy in higher education, next section deals with the topic of sustainability literacy in higher education, followed by a section on educating for sustainability literacy in higher education. The following section addresses the role of Sociology of Education in the promotion of sustainability literacy: what to learn and how to learn Sociology of Education and ESD. Through a selective review, the importance of Sociology of Education in increasing sustainability literacy in higher education is discussed, embodied in the use of key competencies and the Sustainable Development Goals (SDGs) [13], which are a reference in this field. Finally, the article seeks to show, through illustrative examples, that there are SDGs whose learning would directly benefit from the use of a sociological stance and action throughout the whole learning process. This sociological input would address dimensions such as the interconnection of scale levels, sociological imagination, multi-paradigmatic nature, heuristic interdisciplinarity, reflexivity and the resource to Sociology for action through its use in situations of informed and intentional knowledge.

\section{Sustainability literacy in higher education}

\subsection{Sustainability}

The concept of sustainability was first introduced in education worldwide by the UNESCOUNEP International Environmental Education Program in 1975. Since then, several declarations have been signed, both nationally and internationally, to develop sustainability in HEIs. These include the 1990 Talloires Declaration - the first official declaration issued by HEI leaders -, the 1993 Swansea Declaration, the 1994 CRE COPERNICUS Charter for Sustainable Development, the 2001 Lüneburg Declaration on Higher Education for Sustainable Development, and more recently the 2004 Graz Declaration [27].

The term sustainability is, therefore, widely used in the contemporary world. However, it is very often confined to pure rhetoric and is, to some extent, already part of the normative and/or political $[19,32]$ common sense [7] and sometimes in an uncritical way.

This is a still very fragmented field $[5,19,33,34]$, and the concept of sustainability has, to some extent, different definitions depending on the subject area [5,8,1,25,35,36, 37]. What is exactly sustainability? The following proposal seems a relevant contribution to the definition of this concept:

Sustainability is often spoken of in terms of the "Three Es" - economics, ecology, and (social) equity. The commonly accepted definition of general sustainability usually invokes a vision of human welfare that takes into consideration inter- as well as intra-generational equity, and which does not exceed the limits of 
natural resource bases. In other words, it is a vision of a society which neither borrows from future generations nor lives at the expense of current generations [10] (p. 60).

The United Nations themselves propose 17 SDGs that go far beyond sheer environmental sustainability, encompassing areas as broad as eradication of poverty and hunger; promotion of health and well-being for all; access of all to education; empowerment of women and gender equality; sustainable management of natural resources; sustainable economic growth and full employment; promotion of sustainable industrialisation and innovation; reduction of asymmetries between countries; promotion of inclusive, safe, resilient and sustainable cities; fight against climate change and its impacts; preservation and sustainable development of marine and terrestrial ecosystems; promotion of inclusive societies; access to justice for all; and, in general, strengthening of the implementation of sustainable development [14]. For all of the above, for a sustainable development, several dimensions have to be considered, such as the economic, social and environmental dimensions [11,12,14,34,38,39].

\subsection{Sustainability literacy}

From the foregoing results the importance in developing sustainability literacy of each citizen, so that he/she is able to display competencies and attitudes of respect for the present thinking about the future, safeguarding it in a mindful and intentional way $[11,34,40,41,42,43]$.

Notwithstanding the several definitions for this concept, according to Décamps, Barbat, Carteron, Hands and Parkes [44], sustainable literacy can be defined as

[...] the knowledge, skills, and mindsets that help compel an individual to become deeply committed to building a sustainable future and allow him or her to make informed and effective decisions to this end. [...] As Sustainable Development is by nature complex and transversal, achieving sustainability literacy requires multidisciplinary approaches and exploration not only of various themes (e.g. soil quality, forest health, social inclusion, etc.) within sustainable development but also the interconnectedness of these themes (p. 141).

The importance of sustainability literacy is such that there are tests to measure it. One example is Sulitest (Sustainability Literacy Test), which is an internationally developed and widely implemented open online tool [44,45]. This test can be taken online by higher education students and aims to identify the knowledge of this population segment regarding local and global issues that relate to SD, so as to assess, know, spread and promote literacy in this field [46].

Sustainable development, for which the development of sustainability literacy is paramount through the process of its learning [47], entails a shift in the societal paradigm, in which "Sufficiency" is a core value [48]. Sustainability literacy has a great complexity by affecting, we recall, multiple dimensions, such as the economic, environmental, technological, cultural, societal and political ones, both in the production and consumption of goods and services [9,12,19,49].

In this process, scientific knowledge and higher education are vital.

\subsection{Scientific knowledge and higher education}

Science for sustainability may, thus, be considered as a complex system $[17,50,51,52]$. However, as early as 1998, Passerini [10] considered that the social dimension was somewhat lacking in the analysis and promotion of sustainability, specifically the sociological science. Even today the dimension of the humanities and social sciences, including Sociology, both in theoretical and in empirical terms, is not sufficiently used and incorporated into the analysis of SD. This reduces the effectiveness of both research, and teaching and participation $[3,7,20,21,53]$ that is sought after in an increasingly developed society.

In this context, according to UNESCO [13,28], O'Brien et al. [53], and Kopnina and Cocis [54], lifelong education, in its formal, non-formal and/or informal dimensions, is a key element in meeting this complex challenge of a shift in attitudes and practices regarding the promotion of sustainability. Higher education is one of the central pathways for this transformation. Higher education may, in fact, make an important contribution to this paradigmatic transformation, both through education and through research and dissemination [25,42,44,55,56,57]. 
However, the institutionalisation of sustainability in HEIs is neither easy nor automatic and faces numerous challenges and difficulties [35]. Indeed, over the last few years, HEIs have focused essentially on their own sustainability and survival, and these institutional priorities have not fully integrated the development and implementation of a broad sustainability literacy that leads to a societal transformation from an unsustainable development towards more sustainable solutions in social and environmental terms [15,58].

In this context, how to educate for sustainability literacy?

\section{Educating for Sustainability Literacy in Higher Education}

A relevant question that arises from this topic is the need to distinguish education from sustainable development [33,59]. This positioning seems to refer to something close to sustainability literacy, given the need to attain competencies that are intentionally used as social learning $[49,60]$.

Ansari and Stibbe [40] (pp. 435 and 436) offer an interesting perspective on the learning of sustainability literacy by associating the concept of sustainability with the skills and competencies required for its literacy, as depicted in Figure 1 below.

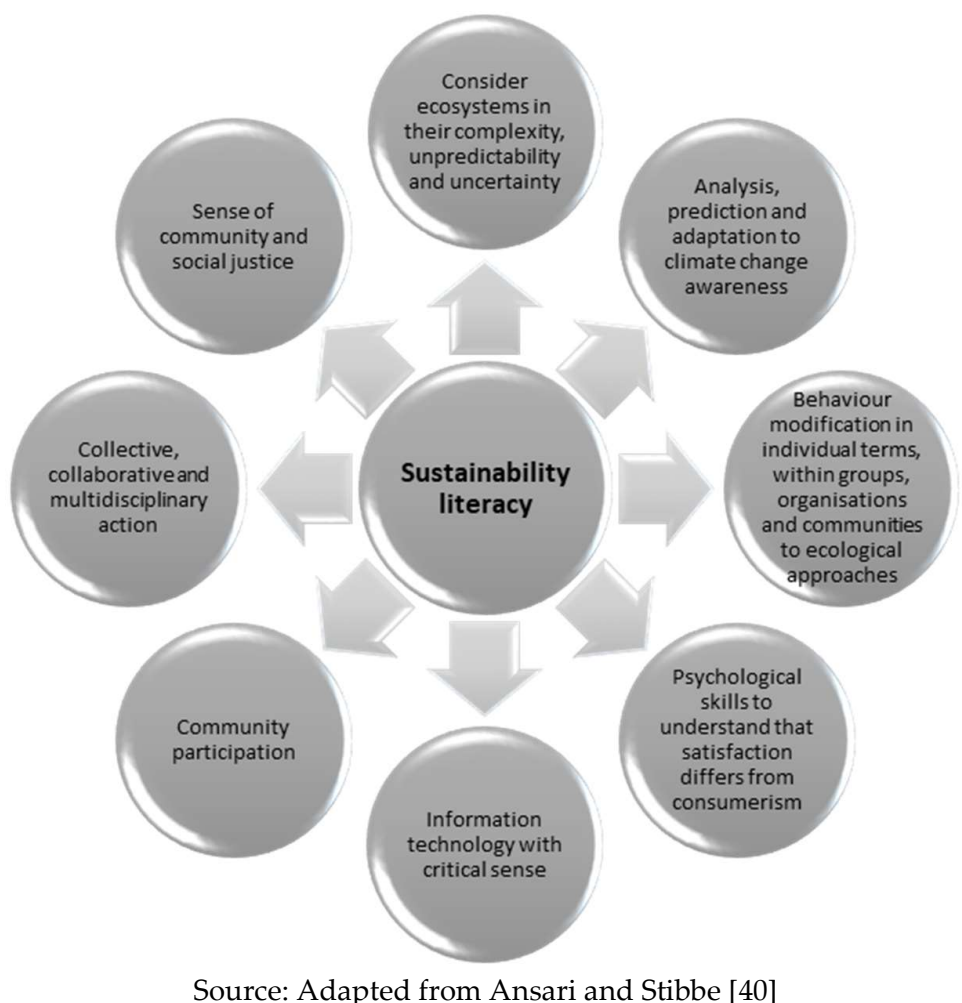

Figure 1. Sustainability literacy and associated skills and competencies

UNESCO proposes the following 17 SDGs: 1. No Poverty; 2. Zero Hunger; 3. Good Health and Well-Being; 4. Quality Education; 5. Gender Equality; 6. Clean Water and Sanitation; 7. Affordable and Clean Energy; 8. Decent Work and Economic Growth; 9. Industry, Innovation and Infrastructure; 10. Reduced Inequalities; 11. Sustainable Cities and Communities; 12. Responsible Consumption and Production; 13. Climate Action; 14. Life below Water; 15. Life on Land; 16. Peace, Justice and Strong Institutions; 17. Partnerships for the Goals [13,61]. This organisation $[13,28]$ (p. 63) sustains that education is vital to foster these SDGs and sustainability competencies, and advocates the centrality of education (SD4) "for the achievement of sustainable development, and Education for Sustainable Development is particularly needed because it empowers learners to make informed decisions and act responsibly for environmental integrity, economic viability and a just society, for present and future generations". Such a positioning also entails, in this field of ESD, the implementation of active 
learning activities that are relevant to students $[13,25,56]$. UNESCO [13] further argues that, for an effective ESD, there must be a shift in the educational paradigm, inasmuch that the vision of education as teaching must be abandoned in order to adopt the vision of education as learning. This new orientation of education entails the adoption of a self-directed, participatory and collaborative learning, oriented towards problem-solving, that is inter- and trans-disciplinary, that links formal and informal learning, with the student always playing the central role in this new form of access to knowledge [13].

Kolb, Fröhlich and Schmidpeter's [62] perspective is heuristically interesting, by articulating the possible influences of the SDGs, and which values the importance of education, by considering that SDG4 has a direct impact on SDGs 8, 9, 12 and 17; in turn, innovation fosters the SDGs 6, 7, 14 and 15, which, finally, will lead to SDGs 1, 2, 3, 5, 10, 11, 13 and 16.

In this centrality of teaching and learning processes in education for a culture of sustainability [63,64], HEIs have several social, environmental and economic responsibilities. SD in universities implies, then, several elements that relate to each other in addition to teaching and learning $[17,18]$, and changing the formal curriculum does not suffice [18,33,37,62]. It is also necessary: "( 1 ) sustainability-focused education and teaching; (2) sustainability-focused research; (3) campus operations and environmental management; and (4) community engagement around sustainability issues" [66] (p. 418).

But what can be the contribution of Sociology of Education in the promotion of sustainability literacy?

\section{Sociology of Education in the promotion of sustainability literacy}

\subsection{What to learn}

For the purposes of this article, and given the importance and centrality of UNESCO's 2017 document - Education for Sustainable Development Goals: Learning Objectives [13] -, we will use it in detail by selecting several examples provided to illustrate the role of Sociology of Education in ESD.

According to UNESCO [13], ESD involves eight important key competencies for sustainability. The first is the systems thinking competency, which entails the ability to "recognise and understand relationships; to analyse complex systems; to think of how systems are embedded within different domains and different scales; and to deal with uncertainty" [13] (p. 10). The second is the anticipatory competency, and includes the ability to "understand and evaluate multiple futures - possible, probable and desirable; to create one's own visions for the future; to apply the precautionary principle; to assess the consequences of actions; and to deal with risks and changes" (p. 10). The third is the normative competency, which relates to the ability to "understand and reflect on the norms and values that underlie one's actions; and to negotiate sustainability values, principles, goals, and targets, in a context of conflicts of interests and trade-offs, uncertain knowledge and contradictions" (p. 10). The fourth is the strategic competency, that is, the ability to "collectively develop and implement innovative actions that further sustainability at the local level and further afield" (p. 10). The fifth competency is linked to collaboration, that is, the ability to "learn from others; to understand and respect the needs, perspectives and actions of others (empathy); to understand, relate to and be sensitive to others (empathic leadership); to deal with conflicts in a group; and to facilitate collaborative and participatory problem solving" (p. 10). The sixth is the critical thinking competency, and involves the ability to "question norms, practices and opinions; to reflect on own one's values, perceptions and actions; and to take a position in the sustainability discourse" (p. 10). The seventh competency relates to self-awareness and entails the need to "reflect on one's own role in the local community and (global) society; to continually evaluate and further motivate one's actions; and to deal with one's feelings and desires" (p. 10). Finally, the eighth is the integrated problem-solving competency, that is, the "overarching ability to apply different problem-solving frameworks to complex sustainability problems and develop viable, inclusive and equitable solution options that promote sustainable development, integrating the above mentioned competences" (p. 10). 
The competencies set out above have the core objective of fostering the following SDGs, each of which includes sub-objectives of three dimensions: cognitive (c), socio-emotional (se) and behavioural (b):

The cognitive domain comprises knowledge and thinking skills necessary to better understand the SDG and the challenges in achieving it.

The socio-emotional domain includes social skills that enable learners to collaborate, negotiate and communicate to promote the SDGs as well as self-reflection skills, values, attitudes and motivations that enable learners to develop themselves.

The behavioural domain describes action competencies [13] (p. 10)

The aforementioned 17 SDGs are depicted in Table 1 (for a complete development, see [13]).

Table 1. Sustainable Development Goals

\begin{tabular}{|c|c|c|c|c|c|c|c|}
\hline \multicolumn{8}{|c|}{$\begin{array}{l}\text { SDG 4: Quality Education - Ensure inclusive and equitable quality } \\
\text { education and promote lifelong learning opportunities for all }\end{array}$} \\
\hline \multicolumn{8}{|c|}{ Direct impact in } \\
\hline \multicolumn{2}{|c|}{$\begin{array}{l}\text { SDG 8: Decent Work and } \\
\text { Economic Growth - Promote } \\
\text { sustained, inclusive and } \\
\text { sustainable economic } \\
\text { growth, full and productive } \\
\text { employment and decent } \\
\text { work for all. }\end{array}$} & \multicolumn{2}{|c|}{$\begin{array}{l}\text { SDG 9: Industry, } \\
\text { Innovation and } \\
\text { Infrastructure - Build } \\
\text { infrastructure, promote } \\
\text { inclusive and } \\
\text { sustainable } \\
\text { industrialisation and } \\
\text { foster innovation. }\end{array}$} & \multicolumn{2}{|c|}{$\begin{array}{l}\text { SDG 12: Responsible } \\
\text { Consumption and Production } \\
\text { - Ensure sustainable } \\
\text { consumption and production } \\
\text { patterns. }\end{array}$} & \multicolumn{2}{|c|}{$\begin{array}{l}\text { SDG 17: Partnerships for the } \\
\text { Goals - Strengthen the } \\
\text { implementation and } \\
\text { revitalise the global } \\
\text { partnership for sustainable } \\
\text { development. }\end{array}$} \\
\hline \multicolumn{8}{|c|}{ Innovation fosters } \\
\hline \multicolumn{2}{|c|}{$\begin{array}{l}\text { SDG 6: Clean Water and } \\
\text { Sanitation - Ensure } \\
\text { availability and sustainable } \\
\text { management of water and } \\
\text { sanitation for all. }\end{array}$} & \multicolumn{2}{|c|}{$\begin{array}{l}\text { SDG 7: Affordable and } \\
\text { Clean Energy - Ensure } \\
\text { access to affordable, } \\
\text { reliable, sustainable } \\
\text { and clean energy for } \\
\text { all. }\end{array}$} & \multicolumn{2}{|c|}{$\begin{array}{l}\text { SDG 14: Life below Water - } \\
\text { Conserve and sustainably use } \\
\text { the oceans, seas and marine } \\
\text { resources for sustainable } \\
\text { development. }\end{array}$} & \multicolumn{2}{|c|}{$\begin{array}{l}\text { SDG 15: Life on Land - } \\
\text { Protect, restore and promote } \\
\text { sustainable use of terrestrial } \\
\text { ecosystems, sustainably } \\
\text { manage forests, combat } \\
\text { desertification, and halt and } \\
\text { reverse land degradation and } \\
\text { halt biodiversity loss. }\end{array}$} \\
\hline $\begin{array}{l}\text { SDG 1: No } \\
\text { Poverty - } \\
\text { End poverty } \\
\text { in all its } \\
\text { forms } \\
\text { everywhere. }\end{array}$ & $\begin{array}{l}\text { SDG 2: Zero } \\
\text { Hunger - } \\
\text { End hunger, } \\
\text { achieve food } \\
\text { security and } \\
\text { improved } \\
\text { nutrition } \\
\text { and promote } \\
\text { sustainable } \\
\text { agriculture. }\end{array}$ & $\begin{array}{l}\text { SDG 3: } \\
\text { Good } \\
\text { Health } \\
\text { and Well- } \\
\text { being - } \\
\text { Ensure } \\
\text { healthy } \\
\text { lives and } \\
\text { promote } \\
\text { well- } \\
\text { being for }\end{array}$ & $\begin{array}{l}\text { SDG 5: } \\
\text { Gender } \\
\text { Equality - } \\
\text { Achieve } \\
\text { gender } \\
\text { equality } \\
\text { and } \\
\text { empower } \\
\text { all women } \\
\text { and girls. }\end{array}$ & $\begin{array}{l}\text { SDG 10: } \\
\text { Reduced } \\
\text { Inequalities } \\
\text { - Reduce } \\
\text { inequality } \\
\text { within and } \\
\text { among } \\
\text { countries. }\end{array}$ & $\begin{array}{l}\text { SDG 11: } \\
\text { Sustainable } \\
\text { Cities and } \\
\text { Communities } \\
\text { - Make } \\
\text { cities and } \\
\text { human } \\
\text { settlements } \\
\text { inclusive, } \\
\text { safe, resilient } \\
\text { and } \\
\text { sustainable. }\end{array}$ & $\begin{array}{l}\text { SDG 13: } \\
\text { Climate } \\
\text { Action - } \\
\text { Take } \\
\text { urgent } \\
\text { action to } \\
\text { combat } \\
\text { climate } \\
\text { change } \\
\text { and its } \\
\text { impacts. }\end{array}$ & $\begin{array}{l}\text { SDG 16: Peace, } \\
\text { Justice and } \\
\text { Strong } \\
\text { Institutions - } \\
\text { Promote } \\
\text { peaceful and } \\
\text { inclusive } \\
\text { societies for } \\
\text { sustainable } \\
\text { development, } \\
\text { provide access } \\
\text { to justice for all }\end{array}$ \\
\hline
\end{tabular}




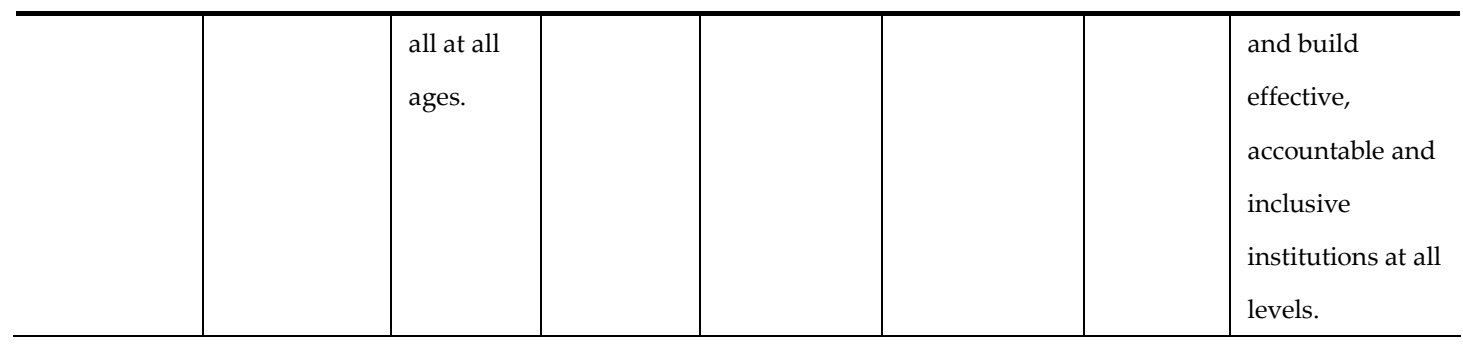

Source: Selection of content from UNESCO [13] and Kolb et al. [62].

Following the information depicted in Table 1, this article posits that the quality of education (SDG4) is a critical element for the promotion of sustainable literacy [13].

Thus, the following question emerges: How can Sociology of Education contribute to the promotion of sustainability literacy in higher education? Next subsection seeks to provide answers to this question.

\subsection{How to learn}

\subsubsection{Sociology of Education}

Carteron et al. [65] put forward several areas in which sustainability can be promoted, among which the following are highlighted: (i) the pedagogical approach used; (ii) the curriculum content; (iii) the "learning by doing" methodology; (iv) mandatory courses; (v) a holistic and system thinking approach; and (vi) transversal research.

Accordingly, and as a broad framework of this contribution to the discussion of the topic under analysis, Sociology of Education and also Sociology of Higher Education have close links with Sociology, with connections that can be deepened $[67,68,69,70,71,72,73,74]$. This article uses conceptualisations, models and theories from Sociology to frame and "understand the processes of education in its social sphere" [75] (p. 276). But how to promote, through the use of Sociology of Education in higher education, these objectives and competencies of quality, equitable, inclusive education, that foster literacy for sustainable development?

This article considers the following features of Sociology of Education, as a specialised sociological field, that relate to ESD: interconnection of scale levels, sociological imagination, multiparadigmatic nature, heuristic interdisciplinarity, reflexivity, and use of Sociology for action (which will be developed and applied ahead).

Sociology, as scientific knowledge, entails a rigorous and controlled stance of the micro-, mesoand macro-social reality [76,77,78,79]. On the integration of scale levels, Claude Javeau [78] maintained that social relationships refer to individual interactions and occur when framed and conditioned by the level of social relationships that take place between groups structured in a given social hierarchy, and both are inscribed in a broader level [70,78].

Ferreira and Serpa [76] put forward the following features: sociological imagination, its multiparadigmatic nature, heuristic interdisciplinarity, and reflexivity. Following these principles, Sociology of Education seeks to demystify the wrong, but commonly shared, concepts about the social. A sociological imagination is vital in Sociology [80]; it is multi-paradigmatic, with the possibility of a plural use of several paradigms in the construction of its object of study and consequent analysis; it needs to be receptive to a heuristic interdisciplinarity, in a certain logic of complementarity between the various social sciences; and, finally, it should promote reflexivity at several levels, as a science that fosters the critical analysis of its own activity, as well as its relationship with the society it analyses (for further development, see Ferreira and Serpa [76] and Serpa [70]).

This article advocates the use of Sociology for action, given that Sociology of Education has a component of implementation, which, in this case, is to foster a quality ESD.

Being the principles integrated among each other, for the purpose of analysis, some of the aforementioned key competencies were selected, as well as a number of SDGs [13] as competencies to be learnt and developed in ESD, and Table 2 below depicts the result of this exercise. For analytical 
purposes and considering the space limitations, as well as the goals of the article, and bearing in mind that SDG4 and integrated problem-solving encompasses all other competencies [13], we have selected the correspondence of sociological features of Sociology of Education with ESD that seemed closer.

Table 2. Relationship between Sociology of Education and key competencies with examples of SDGs

\begin{tabular}{|c|c|c|}
\hline $\begin{array}{c}\text { Correspondence } \\
\text { between features of } \\
\text { Sociology of } \\
\text { Education and ESD }\end{array}$ & Key Competencies & Examples of SDG specific goals \\
\hline $\begin{array}{l}\text { Use of Sociology for } \\
\text { educational action }\end{array}$ & $\begin{array}{l}\text { - strategic; } \\
\text { - collaboration; } \\
\text { - integrated } \\
\text { problem-solving. }\end{array}$ & $\begin{array}{l}\text { 17.3. The learner is able to become a change agent to realise the SDGs and } \\
\text { to take on their role as an active, critical and global and sustainability } \\
\text { citizen. } \\
\text { 1.2. The learner is able to collaborate with others to empower individuals } \\
\text { and communities to affect change in the distribution of power and } \\
\text { resources in the community and beyond. } \\
\text { 11.3. The learner is able to co-create an inclusive, safe, resilient and } \\
\text { sustainable community. }\end{array}$ \\
\hline $\begin{array}{l}\text { Sociological } \\
\text { imagination }\end{array}$ & $\begin{array}{l}\text { - normative; } \\
\text { - critical thinking; } \\
\text { - integrated } \\
\text { problem-solving. }\end{array}$ & $\begin{array}{l}\text { 2.2. The learner is able to reflect on their own values and deal with } \\
\text { diverging values, attitudes and strategies in relation to combating hunger } \\
\text { and malnutrition and promoting sustainable agriculture. } \\
\text { 5.2. The learner is able to recognise and question traditional perception of } \\
\text { gender roles in a critical approach, while respecting cultural sensitivity. } \\
\text { 16.2. The learner is able to reflect on their own personal belonging to } \\
\text { diverse groups (gender, social, economic, political, ethnical, national, } \\
\text { ability, sexual orientation etc.) their access to justice and their shared sense } \\
\text { of humanity. }\end{array}$ \\
\hline $\begin{array}{l}\text { Interconnection of } \\
\text { scale levels }\end{array}$ & $\begin{array}{l}\text { - systems thinking; } \\
\text { - self-awareness; } \\
\text { - integrated } \\
\text { problem-solving }\end{array}$ & $\begin{array}{l}\text { 2.1. The learner knows the main drivers and root causes for hunger at the } \\
\text { individual, local, national and global level. } \\
\text { 13.1. The learner knows about the main ecological, social, cultural and } \\
\text { economic consequences of climate change locally, nationally and globally } \\
\text { and understands how these can themselves become catalysing, } \\
\text { reinforcing factors for climate change. } \\
\text { 13.3. The learner is able to anticipate, estimate and assess the impact of } \\
\text { personal, local and national decisions or activities on other people and } \\
\text { world regions. }\end{array}$ \\
\hline $\begin{array}{l}\text { Multi-paradigmatic } \\
\text { nature }\end{array}$ & $\begin{array}{l}\text { - critical thinking; } \\
\text { - integrated } \\
\text { problem-solving. }\end{array}$ & $\begin{array}{l}\text { 12.3. The learner is able to challenge cultural and societal orientations in } \\
\text { consumption and production. } \\
\text { 15.2. The learner is able to question the dualism of human/nature and } \\
\text { realises that we are a part of nature and not apart from nature. } \\
\text { 3.2. The learner is able to create a holistic understanding of a life of health }\end{array}$ \\
\hline $\begin{array}{l}\text { Heuristic } \\
\text { interdisciplinarity }\end{array}$ & - systems thinking; & $\begin{array}{l}\text { 8.1. The learner understands the concepts of sustained, inclusive and } \\
\text { sustainable economic growth, full and productive employment, and }\end{array}$ \\
\hline
\end{tabular}




\begin{tabular}{|c|c|c|}
\hline & $\begin{array}{l}\text { - integrated } \\
\text { problem-solving. }\end{array}$ & $\begin{array}{l}\text { decent work, including the advancement of gender parity and equality, } \\
\text { and knows about alternative economic models and indicators. } \\
\text { 15.1. The learner understands that realistic conservation strategies work } \\
\text { outside pure nature reserves to also improve legislation, restore degraded } \\
\text { habitats and soils, connect wildlife corridors, sustainable agriculture and } \\
\text { forestry, and redress humanity's relationship to wildlife. } \\
\text { 11.2. The learner is able to reflect on their region in the development of } \\
\text { their own identity; understanding the roles that the natural, social and } \\
\text { technical environments have had in building their identity and culture. }\end{array}$ \\
\hline
\end{tabular}

Source: own production, on the basis of Ferreira and Serpa [76], Serpa [70] and UNESCO [13]

\subsubsection{Sociology of Education and quality ESD}

The use of Sociology for educational action

Davies [81] and Donnelly [82] advocate that, since learning is a social phenomenon, it cannot be confined to the formal environment of educational institutions. It is an active and permanent process throughout the life of the individual, which may occur not only in formal educational spaces but virtually anywhere, at any time, with any interlocutor $[70,71,73,80]$.

Specifically on Sociology of Education, according to Cárdenas, Piñón, and Orozco [75] (p. 276), Sociology of Education is the discipline of choice to study behaviours and interactions underlying the educational process, reinforcing this idea:

[...] Sociology to understand the educational processes in their social domain. It is through Sociology of Education that behaviours and interactions inherent in the educational process can be studied. Education should be understood as a complex process, where educational agents are not only teachers in a classroom; rather, education is inherent in all its forms: formal, non-formal and informal, and each of these with its multiple agents are those they favour the educational process.

Regarding specific learning in higher education in general, Halsall, Powell and Snowden [55], Aragon-Correa, Marcus, Rivera and Kenworthy [59], Hedden, Worthy, Akins, Slinger-Friedman and Paul [56], Bizerril, Rosa, Carvalho and Pedrosa [35], Ortiz and Huber-Heim [83], Arends [84], Strode [85], Jacobs [86], Balakrishnan and Claiborne [87], Jones, Baran and Steuber [88], Kindon and Elwood [89] and Kersten, Crul, Geelen, Meijer and Franken [90] stress the need for an active learning. Arends [84] emphasises the need to implement several learning practices so as to make learning profitable and more efficient, considering the learning objectives, the environmental conditions and the traits of both students and teachers.

It is acknowledged that social features such as culture, race, class, gender, educational level, resources, power and ideology potentially affect sustainability literacy [3,10,91]. For example, and according to Passerini [10] (p. 62), "how society responds to environmental issues often has social foundations rather than technical foundations, involving social action, institutions, organisations, 
relationships, culture, motivation, values, meaning, norms, and other social processes". All these variables make the learning and teaching process quite complex $[56,92]$.

Davies [81] offers six concomitant strategies to foster the learning of sustainability, in general: (i) creating learning communities (real or virtual, formal or otherwise, with an active participation of all members); (ii) learning from experience (lived experience in a more active learning); (iii) fostering a new cultural worldview (in the respect for Earth's diversity); (iv) thinking systemically (systemic thinking would focus on understanding the interactions between human and ecological systems, and restructuring human systems to be more sustainable); (v) embracing diversity (cultural diversity, different cultures and ethnicities, but also different ideas, beliefs and ways of knowing); and (vi) whole person learning.

UNESCO [13] (p. 7) itself maintains that "What ESD requires is a shift from teaching to learning", fostering active learning [64]. For instance, according to Selwyn and Facer [93] (p. 483), "opportunities for sociologists of education to explore ways of engaging in the active construction of educational practices and institutions that reflect, challenge and build upon the wider socio-technical changes of today".

Therefore, Sociology of Education can collaborate in the success of the educational action, both in key competencies (strategic; collaboration; integrated problem-solving), and in the following SDGs: (i) 17.3. The learner is able to become a change agent to realise the SDGs and to take on their role as an active, critical and global and sustainability citizen; (ii) 1.2. The learner is able to collaborate with others to empower individuals and communities to affect change in the distribution of power and resources in the community and beyond; and (iii) 11.3. The learner is able to co-create an inclusive, safe, resilient and sustainable community.

According to Hedden et al. [56], an active learning constructivist approach to the teaching of sustainability-related topics in higher education is critical. However, a more active teaching raises difficulties, inasmuch that it goes against the academic culture disseminated both among teachers, students, and even in the community itself, and can be a source of tensions $[15,31,49,53,88,94,95,96,97,98,99]$.

\section{Sociological imagination}

In order for ESD to be effectively promoted in HEIs, they should enable the existence of a set of features that place the students at the centre of the learning and teaching (rather than the teaching and learning) process, allowing them to develop and attain the competencies, abilities, values and knowledge needed to foster sustainable development [1,100], for example, taking on the role of others [88]. Among these features, the most important are the ones that promote lifelong education at all times and places of the individual's life, and that develop responsible citizens in a society that is intended to be democratic, just and equitable [13,37]. As previously mentioned, the key competencies normative, critical thinking, integrated problem-solving, systems thinking and self-awareness are embodied in the following SDGs: (i) 2.2. The learner is able to reflect on their own values and deal with diverging values, attitudes and strategies in relation to combating hunger and malnutrition and promoting sustainable agriculture; (ii) 5.2. The learner is able to recognise and question traditional perception of gender roles in a critical approach, while respecting cultural sensitivity; and (iii) 16.2. The learner is able to reflect on their own personal belonging to diverse groups (gender, social, economic, political, ethnical, national, ability, sexual orientation etc.) their access to justice and their shared sense of humanity.

Albeit the scientific community has been relatively successful in dealing with ecological imagination, it is not yet sufficiently developed. Norgaard [77] (p. 172) offers an example of the potential relevance of sociological imagination regarding climate change. The development and implementation of this sociological imagination may be an important contribution, for example, in the redefinition of the four issues that are currently the focus of the interdisciplinary discussion on climate change: "why climate change is happening, how we are being impacted, why we have failed to successfully respond so far, and how we might be able to effectively do so". According to the 
author, Sociology, by focusing, more than any other scientific field of studies, on the interactive dimensions of the social order between individuals and social, cultural and economic systems, is in a privileged position to take the lead in this discussion. For the author [77] (p. 171), two types of imagination are necessary to understand and be able to respond to the problem of climate change: "1) to see the relationships between human actions and their impacts on earth's biophysical system (ecological imagination) and 2) to see the relationships within society that make up this environmentally damaging social structure (sociological imagination)".

The role of Sociology of Education is very important in deconstructing representations that do not match reality, in a learning and teaching process that promotes sustainability in higher education, which tends to be extraordinary difficult $[64,90,101]$. Furthermore, there is the need to also consider in this process the traits of students with learning difficulties and/or disabilities [102,103].

\section{Interconnection of scale levels}

The key competencies systems thinking, self-awareness and integrated problem-solving are embodied in the following SDGs: (i) 2.1. The learner knows the main drivers and root causes for hunger at the individual, local, national and global level; (ii) 13.1. The learner knows about the main ecological, social, cultural and economic consequences of climate change locally, nationally and globally and understands how these can themselves become catalysers, reinforcing factors for climate change; and (iii) 13.3. The learner is able to anticipate, estimate and assess the impact of personal, local and national decisions or activities on other people and world regions, and are relevant aspects to understand.

However, Décamps et al. [44] (p. 467 and 468) highlight at least three major hindrances to the promotion of ESD in higher education: "faculty members are not sufficiently engaged"; "students do not generally place importance on sustainability and sustainability is not necessarily considered legitimate by all"; and also "being able to assess the impact of ESD initiatives. At the micro and meso levels, Décamps et al. [44] make it clear that one of the challenges sustainability education poses to HEIs is to overcome the difficulty of involving faculty members, who are not a unified group but rather a competitive one, either within sciences or even within the same science [104]. This difficulty is also felt among students, in the learning and teaching of a topic that many consider peripheral in relation to their programs, as well as the assessment of the impact of the initiatives carried out. Even managers may disagree with the relevance of developing this sustainability literacy [11]. All this makes it complex for school to practice what it claims to advocate [15].

In this sense, the success of implementing a constructivist approach to sustainability through an active learning requires top-down and bottom-up initiatives which the entire academic community must adhere to, so that sustainability can be a reality on campus and a concept fully absorbed by students [56,58,105].

HEI's efforts to integrate sustainability into higher education should not, therefore, be confined to students and academics, but must also encompass other relevant stakeholders from the society at large $[31,64,105]$.

The shifts in institutional and legitimacy conditions also affect this learning [71]. For example, Watson, Hegtvedt, Johnson, Parris and Subramanyam [106], in their 2017 study, state that the results obtained point towards the fact that students' perceptions of what institutional leaders support in terms of sustainable development affect their likelihood of having environmental-friendly behaviours, and that the support of peers influences these behaviours. Thus, there is an increasing need for a sustainability on campus itself [107], with the establishment of an integrated culture that is based, in one of its dimensions, on sustainability.

Thus, it is important that HEIs establish and foster a sustainability culture [64,108], where ecological behaviours should be a common practice. To this end, it is essential that HEIs promote systematic and comprehensive initiatives in terms of the academic community as a whole, rather than just circumscribed and localised initiatives, which will hardly have long-term repercussions $[56,106]$. 


\section{Multi-paradigmatic nature}

Sociology of Education has several paradigms and methodologies [71,109,110,111]. The fact that Sociology is multi-paradigmatic is vital $[31,112]$ in this great epistemological complexity at two levels of construction of the scientific object, "(i) the way in which social reality is broken down into data, collected and analysed, and (ii) the way in which this data is framed and made to recursively influence future sociological knowledge production" [116] (p. 98). This feature of Sociology allows fulfilling the learning of the key competencies critical thinking e integrated problem-solving, embodied in the following SDGs: (i) 12.3. The learner is able to challenge cultural and societal orientations in consumption and production; (ii) 15.2. The learner is able to question the dualism of human/nature and realises that we are a part of nature and not apart from nature; and (iii) 1.2. The learner is able to collaborate with others to empower individuals and communities to affect change in the distribution of power and resources in the community and beyond.

\section{Heuristic interdisciplinarity}

The reformulation of power relations is, to some extent, also present in this paradigm shift [49]. Its implementation in the context of higher education has to cope with a very difficult scenario within the traditional academic culture, which tends to be quantitative, unidirectional, top-down, within the framework of traditional power relationships that emerge from expectations in higher education $[89,114]$, and even among scientific areas in which Sociology, let alone Sociology of Education, is not the most respected area of knowledge [71,77]. There are potential difficulties in promoting this interdisciplinarity, such as the management of different perspectives and languages, the type of pedagogy to be implemented and the exposure of each actor, the scientific identity, the curriculum, in sum, academic culture, students' knowledge and both students' and teachers' expectations.

In fact, numerous authors advocate the need for collaboration in the teaching of sustainability as a multi-dimensional problem $[1,5,9,53,59,115]$. This learning and teaching process entails interdisciplinarity, i.e., "the promotion and mobilisation of synergies of two or more different scientific disciplines" [116] (p. 45). This strategy requires, therefore, the joint involvement and effort of academics and practitioners from a variety of disciplinary fields, in a logic of inter- and transdisciplinarity. This will enable initiating a paradigmatic transformation $[4,22,58]$ in the promotion of interdisciplinarity, which is vital for the understanding of sustainability.

And thus, explaining: the key competencies systems thinking and integrated problem-solving are embodied in the following SDGs: (i) 8.1. The learner understands the concepts of sustained, inclusive and sustainable economic growth, full and productive employment, and decent work, including the advancement of gender parity and equality, and knows about alternative economic models and indicators; (ii) 15.1. The learner understands that realistic conservation strategies work outside pure nature reserves to also improve legislation, restore degraded habitats and soils, connect wildlife corridors, sustainable agriculture and forestry, and redress humanity's relationship to wildlife; and (iii) 11.2. The learner is able to reflect on their region in the development of their own identity, understanding the roles that the natural, social and technical environments have had in building their identity and culture.

\section{Reflexivity}

According to Ison [117] (p. 116),

Two promising systems praxis trajectories for improving human-environment relations are explored. The case for systems thinking in practice capacity and capability development concludes the review. [...] Central to reflexivity is being aware that: (i) all practice is situated; (ii) all observations require an observer; (iii) everything said is said by someone; (iv) all knowing is doing, and (v) all observers, practitioners, actors have a history, a tradition of understanding out of which they think and act.

At the institutional level, Bizerril et al. [35], in their work on sustainability in higher education in Portuguese-speaking countries, conclude that the culture of HEIs is a central aspect in this process. 
This reflexivity also implies the awareness that the formal dimension [118] alone is not enough to promote sustainability literacy.

Considering the informal dimension is also critical [33, 119]. O'Brien et al. [53] (p. 54) point out that there is a tendency, in the current positioning of teaching institutions, to envisage scientific knowledge as "a truth that needs to be communicated to 'users', often ignoring other types of knowledge or perspectives", in an often uncritical stance towards knowledge. Thus, the authors advocate the need for a renewed approach in the shift from "science for society" to "science with society".

This new approach requires that HEIs provide their students with space for reflection and questioning, experiential learning, and the development of personal competencies, such as the ability to reflect, think critically and respect diversity. However, there is still some resistance as to the effectiveness of this positioning of divergence in relation to the current way of learning [33]. In this line, Cotton and Alcock [120] argue that higher education plays an essential role in environmental sustainability by encouraging students to develop cognitive skills in an institutional environment characterised by the defense of environmental values and behaviours and by the promotion of the development in institutional actors of ideological commitment. Colucci-Gray, Camino, Barbiero and Gray [121] confirm this notion of complexity and difficulty in the development of a sustainability literacy, as well as in the teaching of science itself.

For Li and Zhou [6], Massive Open Online Courses (MOOCs) themselves are a novelty with a possible high potential to be considered for sustainability education. However, technology is not neutral. As stated by Selwyn and Facer [93] (p. 491), "[...] This implies an increased interest in developing a 'live sociology' of digital technology and education-i.e. sociological work that is inventive, creative and makes a practical contribution".

Ideology and power relationships are always present in any educational process $[4,66,122]$. The strongly rooted interests and powers may be at stake $[8,12,17,31,36,49,53,123,124]$. Passerini [10] states that economic, environmental and social equity interests are conflicting when discussing the issues of sustainability and the promotion of their literacy in higher education. The author further sustains that, in this discussion, the choices between pragmatism and efficiency, between equity and external costs, between development/growth and ecological sustainability, between sustainability of the status $q u o$ and sustainability are sometimes controversial as to which individuals and/or groups will benefit and which will have to be sacrificed so that sustainability plans and projects are implemented.

All this has to be considered in the promotion of the anticipatory key competencies: critical thinking, self-awareness and integrated problem-solving, embodied in the following SDGs: (i) 18.3. The learner is able to engage with new visions and models of a sustainable, inclusive economy and decent work; (ii) 12.2. The learner is able to differentiate between needs and wants and to reflect on their own individual consumer behaviour in light of the needs of the natural world, other people, cultures and countries, and future generations, and (iii) 13.3. The learner is able to anticipate, estimate and assess the impact of personal, local and national decisions or activities on other people and world regions.

In sum, an education for the creation of a culture of sustainability literacy is indeed a complex process that generates multiple internal and external uncertainties in higher education [17,33]. Hence, it is not possible to offer a unique recipe/way to manage this process [13], given that sustainability is a scientific process, but also a social and political one [33,53, 125].

To foster sustainability literacy in higher education, there is the need of not only a shift in the learning and teaching process but, at the same time, a cultural and societal shift. However, more than that, there is also the need for a change in many HEIs $[53,81,126,127]$, which also encompasses the higher legitimation ascribed to Sociology in the academic world [31]. Sociology has good theoretical and methodological conditions to take an active part in this debate on sustainability, insofar that it adds to the information produced by scientists from the field of physics and economics the important issue of analysing how social systems function [10]. 
This process inevitably involves a stronger presence of Sociology of Education in the curriculum to be implemented, as also a social construction, in a more holistic and integrated practice $[14,15,18,37,41]$.

The challenge, then, is to consider that a certain reinvigoration of Sociology of Education is necessary, as Mehta and Davies [128] (p. 80) explain:

[...] sociologists of education must draw on more of the tools and theoretical insights that have emerged in the field at large. Notions of cultural toolkits, repertoires, fields, institutional logics, linked ecologies, path dependence, frames, and boundaries are just a few of the many prominent ideas in cultural, organizational, and political sociology that are too rarely connected to schooling.

\section{Conclusions}

ESD is, more than ever, an overriding need and is an integral part of political, social, economic and educational agendas. Therefore, it should be developed at all levels of schooling, inasmuch that environmentally friendly behaviours, considered in a broad, way can and should be taught/learnt, promoted and even rewarded so that an environmental awareness can be embedded in students since the first moment.

These concerns about sustainability should naturally also be present in higher education. It is important that the learning and teaching process of sustainability literacy in higher education is taken as a systematic and anticipatory transdisciplinary approach, in the sense of ensuring, through active learning methodologies, that students attain competencies that will enable them to consolidate a lasting environmental awareness [53].

As shown in this article, the sociological perspective has potential in the teaching dimension and may make an important contribution to the success of this challenge [21,75,129]. The three macro, meso and micro dimensions are critical [33], and Sociology of Education, as a sociological field, can provide an important input to its learning by also highlighting the social dimension of education [130] in the learning of both key competencies and SDGs. This sustainability literacy may be potentially promoted through the learning of the interconnection of scale levels, sociological imagination, multi-paradigmatic nature, heuristic interdisciplinarity, reflexivity and use of Sociology for action, as previously maintained.

However, Norgaard [77] acknowledges that Sociology, in general, still has a long way to go in establishing itself as a discipline that is capable of enhancing the scientific community and society at large with its contributions on this topic. In fact, Sociology addresses important issues concerning the centrality of institutional and structural shifts in terms of the economic, political and cultural systems, but its involvement in sustainability issues is not yet adequately developed.

Thus, according to authors such as Lockie [7] and Islam [123], the potential of Sociology and its specialties has not yet been attained in addressing these issues, despite its heuristic ability in the study and promotion of the teaching of sustainability. Sociology can play an important role in the development in students of global citizenship, environmental stewardship, social justice, ethics and wellbeing, and, thus, ensure sustainable futures [33].

In conclusion, Sociology of Education seems to provide a relevant contribution to a sustainability culture [20], a complex and uncertain process [44,57], in which many dimensions are not controllable by teachers [88].

This uncertainty and complexity of ESD are reinforced by UNESCO's [13] (p. 49) recommendations:

There is no 'one size fits all' version of ESD. Political and socio-cultural realities and specific environmental and ecological challenges make a contextual grounding of ESD essential. That is why we need locally and nationally relevant interpretations of ESD and related forms of education.

We believe that this is a challenge and a field with potential for development, for a necessarily integrated shift [9]. Sociology of Education can cooperate with other scientific fields of study for a process that should be, more than formally fast, sustained and, thus, the proverb applies: "If you want to go fast, go alone. If you want to go far, go together" (African proverb), in a sustainability literacy that always takes place throughout life $[13,28]$ and that is vital for ESD. 
15 of 23

Author Contributions: The authors contributed equally for this manuscript.

Funding: University of Azores, Interdisciplinary Centre of Social Sciences-CICS.UAc/CICS.NOVA.UAc, UID/SOC/04647/2013, with the financial support of the FCT/MEC through national funds and when applicable co-financing from the FEDER under the PT2020 Partnership Agreement.

Conflicts of Interest: The authors declare no conflict of interest.

\section{References}

1. Annan-Diab, F.; Molinari, C. Interdisciplinarity: Practical approach to advancing education for sustainability and for the Sustainable Development Goals. The International Journal of Management Education 2017, 15, 2, 73-83. DOI: 10.1016/j.ijme.2017.03.006.

2. Arias-Maldonado, M. The anthropocenic turn: Theorizing sustainability in a postnatural age. Sustainability 2015, 8, 1, 10. DOI: 10.3390/su8010010.

3. Eizenberg, E.; Jabareen, Y. Social sustainability: A new conceptual framework. Sustainability 2017, 9, 1, 68. DOI: $10.3390 / \mathrm{su} 9010068$.

4. Junior, R.D.S.; Ferreira, L.C.; Lewinsohn, T.M. Amid hybridism and polysemy: A sociological analysis of sustainabilities. Ambiente \& Sociedade 2015, XVIII, 4, 35-54. DOI: 10.1590/1809-4422ASOC920V1842015.

5. Kajikawa, Y.; Ohno, J.; Takeda, Y.; Matsushima, K., Komiyama, H. Creating an academic landscape of sustainability science: An analysis of the citation network. Sustainability Science 2007, 2, 2, 221-231. DOI: 10.1007/s11625-007-0027-8.

6. Li, C.; Zhou, H. Enhancing the efficiency of massive online learning by integrating intelligent analysis into MOOCs with an application to education of sustainability. Sustainability 2018, 10, 2, 468. DOI: $10.3390 /$ su10020468.

7. Lockie, S. Sustainability and the future of environmental sociology. Environmental Sociology 2016, 2, 1, 1-4. DOI: $10.1080 / 23251042.2016 .1142692$.

8. Longo, S.; Clark, B.; Shriver, T.; Clausen, R. Sustainability and environmental sociology: Putting the economy in its place and moving toward an integrative socio-ecology. Sustainability 2016, 8, 5, 437. DOI: 10.3390/su8050437.

9. Markard, J.; Raven, R.; Truffer, B. Sustainability transitions: An emerging field of research and its prospects. Research Policy 2012, 41, 6, 955-967. DOI: 10.1016/j.respol.2012.02.013.

10. Passerini, E. Sustainability and sociology. The American Sociologist 1998, 29, 3, 59-70. DOI: 10.1007/s12108998-1005-z.

11. Payne, L. Motivating sustainability literacy. Innovation in and Learning in Information and Computer Sciences 2010, 9, 2, 1-10. DOI: 10.11120/ital.2010.09020005.

12. Teodorescu, A.M. Sustainability development, a multidimensional concept. In Annals of the "Constantin Brâncuşi” University of Târgu Jiu, Economy Series, Special Issue/2015 - Information society and sustainable development, Faculty of Economics, Vol. 0, 2015, pp. 82-86. Academica Brâncuşi" Publisher, ISSN 2344 3685/ISSN-L $1844-700$.

13. UNESCO. Education for Sustainable Development Goals: Learning Objectives. United Nations. Educational, Scientific and Cultural Organization: Paris, France, 2017. Available online: http://unesdoc.unesco.org/images/0024/002474/247444e.pdf (Accessed on 12 May 2018).

14. United Nations. Resolution Adopted by the General Assembly on 25 September 2015. 70/1. Transforming our World: The 2030 Agenda for Sustainable Development. 2015. Available online: http://www.un.org/ga/search/view_doc.asp?symbol=A/RES/70/1\&Lang=E (Accessed on 15 May 2018). 
15. Weybrecht, G. From challenge to opportunity - Management education's crucial role in sustainability and the Sustainable Development Goals - An overview and framework. The International Journal of Management Education 2017, 15, 2, 84-92. DOI: 10.1016/j.ijme.2017.02.008.

16. Winter, J.; Cotton, D. Making the hidden curriculum visible: Sustainability literacy in higher education. Environmental Education Research 2012, 18, 6, 783-796. DOI: 10.1080/13504622.2012.67020.

17. Hugé, J.; Block, T.; Waas, T.; Wright, T.; Dahdouh-Guebas, F. How to walk the talk? Developing actions for sustainability in academic research. Journal of Cleaner Production 2016, 137, 83-92. DOI: 10.1016/j.jclepro.2016.07.010.

18. Alonso-Almeida, M.M.; Marimon, F.; Casani, F.; Rodriguez-Pomeda, J. Diffusion of sustainability reporting in universities: Current situation and future perspectives. Journal of Cleaner Production 2015, 106, 144-154. DOI: 10.1016/j.jclepro.2014.02.008.

19. Burns, T.R. Sustainable development: Agents, systems and the environment. Current Sociology 2016, 64, 6, 875-906. DOI: 10.1177/0011392115600737.

20. Palsson, G.; Szerszynski, B.; Sörlin, S.; Marks, J.; Avril, B.; Crumley, C.; Hackmann, H.; Holm, P.; Ingram, J.; Pardo Buendía, M.; Weehuizen, R. Reconceptualizing the "anthropos" in the anthropocene: Integrating the social sciences and humanities in global environmental change research. Environmental Science $\mathcal{E}$ Policy 2013, 28, 3-13. DOI: 10.1016/j.envsci.2012.11.004.

21. Schroeder, R. The limits to transforming the environment and the limits to sociological. Sustainability 2010, 2, 8, 2483-2498. DOI: 10.3390/su2082483.

22. Shin, D.; Curtis, M.; Huisingh, D.; Zwetsloot, G.I. Development of a sustainability policy model for promoting cleaner production: A knowledge integration approach. Journal of Cleaner Production 2008, 16, 17, 1823-1837. DOI: 10.1016/j.jclepro.2008.06.006.

23. Sureda-Negre, J.; Oliver-Trobat, M.; Catalan-Fernández, A.; Comas-Forgas, R. Environmental education for sustainability in the curriculum of primary teacher training in Spain. International Research in Geographical and Environmental Education 2014, 23, 4, 281-293. DOI: 10.1080/10382046.2014.946322doi:10.1080/10382046.2014.946322.

24. Opoku, A.; Ahmed, V. Understanding sustainability: A view from intra-organizational leadership within UK construction organizations. International Journal of Architecture, Engineering and Construction 2013, 2, 120-130. DOI: 10.7492/IJAEC.2013.012.

25. Opoku, A.; Egbu, C. Students' perspectives on the relevance of sustainability literacy in a postgraduate built environment program. International Journal of Construction Education and Research 2017, 14, 1, 46-58. DOI: 10.1080/15578771.2017.1286417.

26. OECD. Higher Education for Sustainable Development. OECD: Paris, France, 2007.

27. Yarime, M.; Trencher, G.; Mino, T.; Scholz, R.W.; Olsson, L.; Ness, B.; Frantzeskaki, N.; Rotmans, J. Establishing sustainability science in higher education institutions: Towards an integration of academic development, institutionalization, and stakeholder collaborations. Sustain. Sci. 2012, 7, 1, 101-113. DOI: 10.1007/s11625-012-0157-5.

28. UNESCO. Education 2030. Incheon Declaration and Framework for Action. Ensure Inclusive and Equitable Quality Education and Lifelong Learning for All. UNESCO: Paris, France, 2016. Available online: http://uis.unesco.org/sites/default/files/documents/education-2030-incheon-framework-for-actionimplementation-of-sdg4-2016-en_2.pdf (Accessed on 12 June 2018). 
29. Cohen, M.; Wiek, A.; Kay, B.; Harlow, J. Aligning public participation to stakeholders' sustainability literacy - A case study on sustainable urban development in Phoenix, Arizona. Sustainability 2015, 7, 7, 8709-8728. DOI: 10.3390/su7078709.

30. Santos, A.I.; Serpa, S. The importance of promoting digital literacy in higher education. International Journal of Social Science Studies 2017, 5, 6, 90. DOI: 10.11114/ijsss.v5i6.2330.

31. Paredis, E. Sustainability transitions and the nature of technology. Foundations of Science 2010, 16, 2-3, 195225. DOI: 10.1007/s10699-010-9197-4.

32. Guerra, J. Sustentabilidade e os imperativos de equidade social. 40 anos de democracia(s): progressos, contradições e prospetivas [Sustainability and the imperatives of social equity. 40 years of democracy(ies): Progress, contradictions and prospects]. In Atas do VIII Congresso Português de Sociologia [Proceedings of the VIII Portuguese Congress of Sociology], Lisboa, Portugal, Associação Portuguesa de Sociologia, 2014. Available online: http://www.aps.pt/vii_congresso/area=actas\&m=1 (Accessed on 9 April 2018).

33. Cicmil, S.; Gough, G.; Hills, S. Insights into responsible education for sustainable development: The case of UWE, Bristol. The International Journal of Management Education 2017, 15, 2, 293-305. DOI: 10.1016/j.ijme.2017.03.002.

34. Murray, P.E.; Cotgrave, A.J. Sustainability literacy: The future paradigm for construction education? Structural Survey 2007, 25, 1, 7-23. DOI: 10.1108/02630800710740949.

35. Bizerril, M.; Rosa, M.J.; Carvalho, T.; Pedrosa, J. Sustainability in higher education: A review of contributions from Portuguese Speaking Countries. Journal of Cleaner Production 2018, 171, 600-612. DOI: 10.1016/j.jclepro.2017.10.048.

36. Kalberg, S. A transatlantic approach to sustainability? The perspective of sociology. The Environmentalist 2011, 32, 3, 296-299. DOI: 10.1007/s10669-011-9357-2.

37. Yeung, S.M-c. (2016). Seamless learning on institutional sustainable development for quality education and talent development. In Proceedings for the Northeast Region Decision Sciences Institute (NEDSI), Alexandria, Virginia, USA, March 31 - April 2, 2016, pp. 394-427.

38. Muff, K.; Kapalka, A.; Dyllick, T. The gap frame - Translating the SDGs into relevant national grand challenges for strategic business opportunities. The International Journal of Management Education 2017, 15, 2, 363-383. DOI: 10.1016/j.ijme.2017.03.004.

39. Rantala, T.; Ukko, J.; Saunila, M.; Havukainen, J. The effect of sustainability in the adoption of technological, service, and business model innovations. Journal of Cleaner Production 2018, 172, 46-55. DOI: 10.1016/j.jclepro.2017.10.009.

40. Ansari, W.; Stibbe, A. Public health and the environment: What skills for sustainability literacy - and why? Sustainability 2009, 1, 3, 425-440. DOI: 10.3390/su1030425.

41. Kokkarinen, N.; Cotgrave, A.J. Sustainability literacy in action: Student experiences. Structural Survey 2013, 31, 1, 56-66. DOI: 10.1108/02630801311304422.

42. Pashby, K.; Andreotti, V. Ethical internationalisation in higher education: Interfaces with international development and sustainability. Environmental Education Research 2016, 22, 6, 771-787. DOI: 10.1080/13504622.2016.1201789.

43. Somerville, M.; Green, M. Place and sustainability literacy in schools and teacher education. In Proceedings of the AARE APERA International Conference, Sydney, Australia, 2012. Available online: https://files.eric.ed.gov/fulltext/ED544521.pdf (Accessed on 1 June 2018). 
44. Décamps, A.; Barbat, G.; Carteron, J.-C.; Hands, V.; Parkes, C. Sulitest: A collaborative initiative to support and assess sustainability literacy in higher education. The International Journal of Management Education 2017, 15, 2, 138-152. DOI: 10.1016/j.ijme.2017.02.006.

45. Storey, M.; Killian, S.; O'Regan, P. Responsible management education: Mapping the field in the context of the SDGs. The International Journal of Management Education 2017, 15, 2, 93-103. DOI: 10.1016/j.ijme.2017.02.009.

46. Sulitest. What is "Sustainability Literacy"? 2016. Available online: https://www.sulitest.org/ en/vision-mission.html (Accessed on 11 April 2018).

47. Waring, M. Research literacy: Contextual affordances and the ongoing quest for sustainability and research quality. Research Papers in Education 2017, 32, 4, 538-539. DOI: 10.1080/02671522.2017.1322354.

48. Augenstein, K.; Palzkill, A. The dilemma of incumbents in sustainability transitions: A narrative approach. Administrative Sciences 2015, 6, 1, 1. DOI: 10.3390/admsci6010001.

49. Cornell, S.; Berkhout, F.; Tuinstra, W.; Tàbara, J.D.; Jäger, J.; Chabay, I., de Wit, B.; Langlais, R.; Mills, D.; Moll, P.; Otto, I.M.; Petersen, A.; Pohl, C.; van Kerkhoff, L. Opening up knowledge systems for better responses to global environmental change. Environmental Science \& Policy 2013, 28, 60-70. DOI: 10.1016/j.envsci.2012.11.008.

50. Alexandrescu, F.M.; Pizzol, L.; Zabeo, A.; Rizzo, E.; Giubilato, E.; Critto, A. Identifying sustainability communicators in urban regeneration: Integrating individual and relational attributes. Journal of Cleaner Production 2018, 173, 278-291. DOI: 10.1016/j.jclepro.2016.09.076.

51. Vallejos-Romero, A.; Garrido, J. La construcción social del riesgo: Lineamientos para la observación de la conflictividad socioambiental [The social construction of risk: Guidelines for the observation of socioenvironmental conflict]. Andamios, Revista de Investigación Social 2016, 12, 29, 33. DOI: 10.29092/uacm.v12i29.18.

52. Willamo, R.; Helenius, L.; Holmström, C.; Haapanen, L.; Sandström, V.; Huotari, E.; Kaarre, K.; Värre, U.; Nuotiomäki, A.; Happonen, J.; Kolehmainen, L. Learning how to understand complexity and deal with sustainability challenges - A framework for a comprehensive approach and its application in university education. Ecological Modelling 2018, 370, 1-13. DOI: 10.1016/j.ecolmodel.2017.12.011.

53. O’Brien, K.; Reams, J.; Caspari, A.; Dugmore, A.; Faghihimani, M.; Fazey, I.; Hackmann, H.; ManuelNavarrete, D.; Marks, J.; Miller, R.; Raivio, K.; Romero-Lankao, P.; Virji, H.; Vogel, C.; Winiwarter, V. You say you want a revolution? Transforming education and capacity building in response to global change. Environmental Science \& Policy 2013, 28, 48-59. DOI: 10.1016/j.envsci.2012.11.011.

54. Kopnina, H.; Cocis, A. Environmental education: Reflecting on application of environmental attitudes measuring scale in higher education students. Education Sciences 2017, 7, 3, 69. DOI: 10.3390/educsci7030069.

55. Halsall, J.P.; Powell, J.L.; Snowden, M. Determined learning approach: Implications of heutagogy society based learning. Cogent Social Sciences 2016, 2, 1. DOI: 10.1080/23311886.2016.1223904.

56. Hedden, M.K.; Worthy, R.; Akins, E.; Slinger-Friedman, V.; Paul, R. Teaching sustainability using an active learning constructivist approach: Discipline-specific case studies in higher education. Sustainability 2017, 9, 8, 1320. DOI: 10.3390/su9081320.

57. Martin, S.; Jucker, R. Educating earth-literate leaders. Journal of Geography in Higher Education 2005, 29, 1, 19-29. DOI: 10.1080/03098260500030298. 
58. Khoo, A.-M. Sustainable knowledge transformation in and through higher education. A case for transdisciplinary leadership. International Journal of Development Education and Global Learning 2017, 8, 3, 524. DOI: 10.18546/IJDEGL.8.3.02.

59. Aragon-Correa, J.A.; Marcus, A.A.; Rivera, J.E.; Kenworthy, A.L. Sustainability management teaching resources and the challenge of balancing planet, people, and profits. Academy of Management Learning $\mathcal{E}$ Education 2017, 16, 3, 469-483. DOI: 10.5465/amle.2017.0180.

60. Lowther, J.; Sellick, J. Embedding sustainability literacy in the legal curriculum: Reflections on the Plymouth model. The Law Teacher 2016, 50, 3, 307-320. DOI: 10.1080/03069400.2016.1240919.

61. United Nations. About the Sustainable Development Goals. 2018. Available online: https://www.un.org/sustainabledevelopment/sustainable-development-goals/ (Accessed on 6 July 2018).

62. Kolb, M.; Fröhlich, L.; Schmidpeter, R. Implementing sustainability as the new normal: Responsible management education - From a private business school's perspective. The International Journal of Management Education 2017, 15, 2, 280-292. DOI: 10.1016/j.ijme.2017.03.009.

63. Cebrián, G.; Junyent, M. Competencies in education for sustainable development: Exploring the student teachers' views. Sustainability 2015, 7, 3, 2768-2786. DOI: 10.3390/su7032768.

64. Juárez-Nájera, M.; Dieleman, H.; Turpin-Marion, S. Sustainability in Mexican higher education: Towards a new academic and professional culture. Journal of Cleaner Production 2006, 14, 9-11, 1028-1038. DOI: 10.1016/j.jclepro.2005.11.049.

65. Carteron, J.; Haynes, K.; Murray, A. Education for sustainable development, the UNGC PRME initiative, and the sustainability literacy test: Measuring and assessing success. SAM Advanced Management Journal 2014, 79, 4, 51-58. Available online: https://eds.a.ebscohost.com/eds/pdfviewer/pdfviewer?vid=1\&sid= fd7f936f-d9ea-4c26-90c7-5da8109ad8f2\%40sessionmgr4007 20/04/2018 (Accessed on 18 June 2018).

66. Bessant, S.E.F.; Robinson, Z.P.; Ormerod, R.M. Neoliberalism, new public management and the sustainable development agenda of higher education: History, contradictions and synergies. Environmental Education Research 2015, 21, 3, 417-432. DOI: 10.1080/13504622.2014.993933.

67. Miskolczi, P.; Rakovics, M. Learning outcomes in an introductory sociology course: The role of learning approach, socio-demographic characteristics, group and teacher effects. Societies 2018, 8, 1, 4, 1-20. DOI: $10.3390 /$ soc8010004.

68. Dionísio, B.; Torres, L.L.; Alves, M.G. A sociologia da educação em Portugal: Perspetivas de futuro [Sociology of education in Portugal: Future prospects]. Forum Sociológico 2018, 32, 59-69. DOI: 10.4000/sociologico.2098.

69. Vincent, G.; Lahire, B.; Thin, D. Sur l'histoire et la théorie de forme scolaire [On the history and theory of the school form]. In L'Éducation Prisonnière de la Forme Scolaire? [Education Trapped in the School Form?] G. Vincent, Dir.; Presses Universitaires de Lyon: Lyon, France, 1994, pp. 11-48.

70. Serpa, S. A reflection on sociology of education. International Journal of Social Science Studies 2018, 6, 3, 3339. DOI: 10.11114/ijsss.v6i3.3013.

71. Deem, R. Sociology and the sociology of higher education: A missed call or a disconnection? International Studies in Sociology of Education 2004, 14, 1, 21-46. DOI: 10.1080/09620210500200117.

72. Sorokin, P. The ethical challenge for sociology in the face of global modernity: Toward solidarity-oriented and ethically contextualized practice. The American Sociologist 2018, 49, 3, 414-433. DOI: 10.1007/s12108-0189378-0.

73. Bolotin, I.S.; Kozlova, O.N. Sociology and education. Russian Education \& Society 1998, 40, 6, 47-66. DOI: 10.2753/res1060-9393400647. 
74. Beckman, K.; Apps, T.; Bennett, S.; Lockyer, L. Conceptualising technology practice in education using Bourdieu's sociology. Learning, Media and Technology 2018, 43, 2, 197-210, DOI:

10.1080/17439884.2018.1462205.

75. Cárdenas, S.L.; Piñón, F.A.P.; Orozco, G.H. Herramientas de la sociología de la educación aplicadas en la comunidad mormona de LeBaron, en Chihuahua [Tools of sociology of education applied to the LeBaron mormon community in Chihuahua]. Sociológica 2017, 32, 92, 271-285.

76. Ferreira, C.M.; Serpa, S. Challenges in the teaching of sociology in higher education. Contributions to a discussion. Societies 2017, 7, 4, 30, 1-11. DOI: 10.3390/soc7040030.

77. Norgaard, K.M. The sociological imagination in a time of climate change. Global and Planetary Change 2018, 163, 171-176. DOI: 10.1016/j.gloplacha.2017.09.018.

78. Javeau, C. Lições de Sociologia [Lessons of Sociology]; Celta Editora: Oeiras, Portugal, 1998. ISBN: 972-802794-X.

79. Strathdee, R. Reputation in the sociology of education. British Journal of Sociology of Education 2009, 30, 1, 83-96. DOI: 10.1080/01425690802514482.

80. Lange, E. (Re)igniting a sociological imagination in adult education: The continuing relevance of classical theory. International Journal of Lifelong Education 2015, 34, 5, 491-513. DOI: 10.1080/02601370.2015.1028574.

81. Davies, K. Sustainable minds. The next step in human evolution must take environmental learning from schools to the realities of society. Alternatives Journal 2010, 36, 5. Available online: http://www.alternatives journal.ca/sustainable-living/sustainable-minds 20/04/2018 (Accessed on 12 June 2018).

82. Donnelly, M. Inequalities in higher education: Applying the sociology of Basil Bernstein. Sociology 2016, 52, 2, 316-332. DOI: 10.1177/0038038516656326.

83. Ortiz, D.; Huber-Heim, K. From information to empowerment: Teaching sustainable business development by enabling an experiential and participatory problem-solving process in the classroom. The International Journal of Management Education 2017, 15, 2, 318-331. DOI: 10.1016/j.ijme.2017.03.008.

84. Arends, R.I. Aprender a Ensinar [Learning to Teach]; McGraw-Hill de Portugal: Amadora, Portugal, 1999. ISBN: 9788448160104.

85. Strode, A. Participatory action research for development of prospective teachers' professionality during their pedagogical practice. Discourse and Communication for Sustainable Education 2013, 4, 80-90. DOI: 10.2478/dcse-2013-0007.

86. Jacobs, S. The use of participatory action research within education - Benefits to stakeholders. World Journal of Education 2016, 6, 3, 48-55. DOI: 10.5430/wje.v6n3p48.

87. Balakrishnan, V.; Claiborne, L. Participatory action research in culturally complex societies: Opportunities and challenges. Educational Action Research 2017, 25, 2, 185-202. DOI: 10.1080/09650792.2016.1206480.

88. Jones, J.E.; Baran, M.L.; Steuber, J.A. Effective teaching strategies to connect with the adult learners' worldview. In Advances in Educational Technologies and Instructional Design, pp. 84-92, 2019. DOI: 10.4018/978-1-5225-5712-8.ch005.

89. Kindon, S.; Elwood, S. Introduction: More than methods - Reflections on participatory action research in geographic teaching, learning and research. Participatory action research in geographic teaching, learning and research. Journal of Geography in Higher Education 2009, 33, 1, 19-32. DOI: 10.1080/03098260802276474. 
90. Kersten, W.C.; Crul, M.R.M.; Geelen, D.V.; Meijer, S.A.; Franken, V. Engaging beneficiaries of sustainable renovation - Exploration of design-led participatory approaches. Journal of Cleaner Production 2015, 106, 690-699. DOI: 10.1016/j.jclepro.2014.07.060.

91. Vicente-Molina, M.A.; Fernández-Sáinz, A.; Izagirre-Olaizola, J. Environmental knowledge and other variables affecting pro-environmental behaviour: Comparison of university students from emerging and advanced countries. Journal of Cleaner Production 2013, 61, 130-138. DOI: 10.1016/j.jclepro.2013.05.015.

92. Youdell, D. Bioscience and the sociology of education: The case for biosocial education. British Journal of Sociology of Education 2017, 38, 8, 1273-1287. DOI: 10.1080/01425692.2016.1272406.

93. Selwyn, N.; Facer, K. The sociology of education and digital technology: Past, present and future. Oxford Review of Education 2014, 40, 4, 482-496. DOI: 10.1080/03054985.2014.933005.

94. Vivas, H. Presentación tema central edición $N^{\circ}$ 30. Economía y sociología de la educación: Los retos del siglo XXI [Presentation of the central topic of issue No. 30. Economy and sociology of education: The challenges of the 21st century]. Sociedad y Economía 2016, 30, 11-13.

95. Greenberg, D.N.; Deets, S.; Erzurumlu, S.; Hunt, J.; Manwaring, M.; Rodgers, V.; Swanson, E. Signing to living PRME: Learning from a journey towards responsible management education. The International Journal of Management Education 2017, 15, 2, 205-218. DOI: 10.1016/j.ijme.2017.02.007.

96. Serpa, S.; Ferreira, C.M.; Santos, A.I.; Teixeira, R. Participatory action research in higher education training. International Journal of Social Science Studies 2018, 6, 6, 1. DOI: 10.11114/ijsss.v6i6.3286.

97. Neal, S. On the tensions of universities as a social institution - developing a comparative sociology of higher education. Ethnic and Racial Studies 2017, 40, 13, 2285-2292. DOI: 10.1080/01419870.2017.1344269.

98. Wei, Y.; Wu, S.; Tesemma, Z. Re-orienting technological development for a more sustainable humanenvironmental relationship. Current Opinion in Environmental Sustainability 2018, 33, 151-160. DOI: 10.1016/j.cosust.2018.05.022.

99. Woods, L.; Willis, J.; Wright, D.C.; Knapp, T. Building community engagement in higher education: Public sociology at Missouri State University. Journal of Public Scholarship in Higher Education 2013, 3, 6790.

100. Burkholder, K.C.; Devereaux, J.; Grady, C.; Solitro, M.; Mooney, S.M. Longitudinal study of the impacts of a climate change curriculum on undergraduate student learning: Initial results. Sustainability 2017, 9, 6. DOI: $10.3390 /$ su9060913.

101. Andrade, M.S. Curricular elements for learner success - 21st century skills. Journal of Education and Training Studies 2016, 4, 8, 143-149. DOI: 10.11114/jets.v4i8.1743.

102. Tomlinson, S. Is a sociology of special and inclusive education possible? Educational Review 2015, 67, 3, 273-281. DOI: 10.1080/00131911.2015.1021764.

103. Wolbring, G.; Burke, B. Reflecting on education for sustainable development through two lenses: Ability studies and disability studies. Sustainability 2013, 5, 2327-2342; DOI: 10.3390/su5062327.

104. Freitas, A. Para uma sociologia da sociologia do ambiente em Portugal: Um olhar sobre a estrutura de uma comunidade científica [For a sociology of environmental sociology in Portugal: A look on the structure of a scientific community]. In Atas do VI Congresso Português de Sociologia. Mundos Sociais: Saberes e Práticas [Proceedings of the VI Portuguese Congress of Sociology. Social Worlds: Knowledge and Practices]. Lisboa, Portugal, Associação Portuguesa de Sociologia, 2008, pp. 1-15.

105. VanWynsberghe, R.; Andruske, C.L. Research in the service of co-learning: Sustainability and community engagement. Canadian Journal of Education/Revue Canadienne de L'Éducation 2007, 30, 1, 349. DOI: $10.2307 / 20466638$. 
106. Watson, L.; Hegtvedt, K.; Johnson, C.; Parris, C.; Subramanyam, S. When legitimacy shapes environmentally responsible behaviors: Considering exposure to university sustainability initiatives. Education Sciences 2017, 7, 1, 13. DOI: 10.3390/educsci7010013.

107. Velazquez, L.; Munguia, N.; Sanchez, M. Deterring sustainability in higher education institutions. An appraisal of the factors which influence sustainability in higher education institutions. International Journal of Sustainability in Higher Education 2005, 6, 4, 383-391. DOI: 10.1108/14676370510623865.

108. Bullock, C.; Hitzhusen, G. Participatory development of key sustainability concepts for dialogue and curricula at the Ohio State University. Sustainability 2015, 7, 10, 14063-14091. DOI: 10.3390/su71014063.

109. Moore, R. Social realism and the problem of the problem of knowledge in the sociology of education. British Journal of Sociology of Education 2013, 34, 3, 333-353. DOI: 10.1080/01425692.2012.714251.

110. Garner, R.; Hancock, B. Reintegrating theories, methods, and historical analysis in teaching sociology. The American Sociologist 2018, 49, 3, 369-391. DOI: 10.1007/s12108-018-9375-3.

111. Giancola, O.; Viteritti, A. Distal and proximal vision: A multi-perspective research in sociology of education. European Educational Research Journal 2014, 13, 1, 47-57. DOI: 10.2304/eerj.2014.13.1.47.

112. Doherty, C.; Dooley, K.; Woods, A. Teaching sociology within teacher education: Revisiting, realigning and re-embedding. Journal of Sociology 2013, 49, 4, 515-530. DOI: 10.1177/1440783313504062.

113. Au, A. Sociology and science: The making of a social scientific method. The American Sociologist 2017, 49, 1, 98-115. DOI: 10.1007/s12108-017-9348-y.

114. Anderson, G. Participatory action research (PAR) as democratic disruption: New public management and educational research in schools and universities. International Journal of Qualitative Studies in Education 2017, 30(5), 432-449. DOI: 10.1080/09518398.2017.1303211.

115. Stock, P.; Burton, R.J.F. Defining terms for integrated (multi-inter-trans-disciplinary) sustainability research. Sustainability 2011, 3, 8, 1090-1113. DOI: 10.3390/su3081090.

116. Serpa, S.; Ferreira, C.M.; Santos, A.I. Fostering interdisciplinarity: Implications for social sciences. International Journal of Social Science Studies 2017, 5, 12, 44. DOI: 10.11114/ijsss.v5i12.2775.

117. Ison, R. Governing the human-environment relationship: Systemic practice. Current Opinion in Environmental Sustainability 2018, 33, 114-123. DOI: 10.1016/j.cosust.2018.05.009.

118. Torres, L.M.L. Cultura Organizacional em Contexto Educativo. Sedimentos Culturais e Processos de Construção do Simbólico numa Escola Secundária [Organizational Culture in an Educational Context. Cultural Sediments and Symbolic Construction Processes in a Secondary School]. Centro de Investigação em Educação do Instituto de Educação e Psicologia da Universidade do Minho: Braga, Portugal, 2004.

119. Borges, J.C.; Ferreira, T.C.; Borges de Oliveira, M.S.; Macini, N.; Caldana, A.C.F. Hidden curriculum in student organizations: Learning, practice, socialization and responsible management in a business school. The International Journal of Management Education 2017, 15, 2, 153-161. DOI: 10.1016/j.ijme.2017.03.003.

120. Cotton, D.R.E.; Alcock, I. Commitment to environmental sustainability in the UK student population. Studies in Higher Education 2013, 38, 10, 1457-1471. DOI: 10.1080/03075079.2011.627423.

121. Colucci-Gray, L.; Camino, E.; Barbiero, G.; Gray, D. From scientific literacy to sustainability literacy: An ecological framework for education. Science Education 2006, 90, 2, 227-252. DOI: 10.1002/sce.20109.

122. Wolff, L.-A.; Sjöblom, P.; Hofman-Bergholm, M.; Palmberg, I. High performance education fails in sustainability? A reflection on Finnish primary teacher education. Education Sciences 2017, 7, 1, 32. DOI: 10.3390/educsci7010032.

123. Islam, M. Sustainability through the lens of environmental sociology: An introduction. Sustainability 2017, 9, 3, 474. DOI: 10.3390/su9030474. 
124. Edwards, G. Standpoint theory, realism and the search for objectivity in the sociology of education. British Journal of Sociology of Education 2012, 35, 2, 167-184. DOI: 10.1080/01425692.2012.747588.

125. D'Amico, L. Cultivating sustainability literacy and public engagement in Intag, Ecuador. Anthropology in Action 2016, 23, 2, 4-12. DOI: 10.3167/aia.2016.230202.

126. Green, T.L. Teaching (un)sustainability? University sustainability commitments and student experiences of introductory economics. Ecological Economics 2013, 94, 135-142. DOI: 10.1016/j.ecolecon.2013.08.003.

127. Von Blottnitz, H.; Case, J.M.; Fraser, D.M. Sustainable development at the core of undergraduate engineering curriculum reform: A new introductory course in chemical engineering. Journal of Cleaner Production 2015, 106, 300-307. DOI: 10.1016/j.jclepro.2015.01.063.

128. Mehta, J.; Davies, S. We must reinvigorate the sociology of education. Contexts 2018, 17, 2, 80. DOI: $10.1177 / 1536504218776982$.

129. McCright, A.M. Enhancing students' scientific and quantitative literacies through an inquiry-based learning project on climate change. Journal of the Scholarship of Teaching and Learning 2012, 12, 4, 86-102.

130. Chen, X.; Frank, K.A.; Dietz, T.; Liu, J. Weak ties, labor migration, and environmental impacts. Organization E Environment 2012, 25, 1, 3-24. DOI: 10.1177/1086026611436216. 